\title{
Increased incidence of cervical cytological abnormalities in women with genital warts or contact with genital warts: a need for increased vigilance?
}

\author{
D Rowen, C A Carne, C Sonnex, P Cooper
}

\begin{abstract}
Objective-To determine whether women who have a history of genital warts or whose sexual partners have such a history were more likely to have borderline or dyskaryotic cervical smears than other women.

Design-Prospective study conducted over a five month period.

Setting-A genitourinary medicine clinic in Cambridge, UK.

Patients-One hundred and eighty five women who attended the clinic during the study period, on whom cervical cytology was performed. Ninety-seven had a history of genital warts and twenty had partners with genital warts.

Methods-Cervical cytology taken by standard methods. Demographic data and sexual history obtained by questionnaire. Colposcopy was performed on patients with a history of warts or wart contact.

Outcome measured-Relative incidence of cytological abnormalities in the various groups of patients.

Results-"Borderline" nuclear change was the most frequent abnormality reported in the wart contact group (six cases) whereas mild dyskaryosis was the most frequent abnormal finding in those women with a history of warts ( 21 cases).

Conclusions-Women with warts or contact with genital warts were more likely to have borderline or dyskaryotic cervical smears than women without such a history. Recommendations for follow-up of these patients are made.
\end{abstract}

Introduction

There is now considerable evidence of an association between human papillomavirus (HPV) infection and

Department of Genito-Urinary Medicine

D Rowen, C A Carne, C Sonnex

Department of Cytology, Addenbrooke's Hospital, Hills Road, Cambridge, CB2 2QQ, UK

P Cooper cervical neoplasia. ${ }^{1-3}$ Studies have shown that women with a history of genital warts were more likely to have "abnormal" smears than other STD clinic attenders. ${ }^{4}$ Few data are, however, available on the prevalence of abnormal cervical cytology amongst women who have a history of sexual contact with men who have genital warts.

The term "borderline nuclear abnormalities" has been introduced by the British Society for Clinical Cytology into cervical cytology reports in the UK. ${ }^{5-7}$ This category includes smears in which minor nuclear abnormalities occur which do not fulfil the criteria for dyskaryosis yet are greater than the nuclear abnormalities associated with inflammation. This category would therefore include some smears which have been classified, in some centres, as showing "benign atypia". ${ }^{8}$ Currently, however, little is known as to the relationship of this group to a history of genital warts or wart contact.

It has been stated that women with genital warts are no more likely to develop cervical carcinoma than those without warts and thus there was no basis for more frequent screening by either cytology or colposcopy..$^{9}$ Many clinicians would, however, advocate more rigorous screening of women in this group on the basis of increased incidence of $\mathrm{CIN}^{210} 11$ and the difficulty in accurately predicting those who would progress to invasive carcinoma.

The current study was designed to determine whether women with a history of genital warts or who had been in sexual contact with men with genital warts were more likely to have abnormalities of nuclear morphology on cervical cytology than those without a history of warts or contact with warts.

\section{Methods}

Patients having cervical smears taken in our genitourinary medicine clinic, over a 5 month period were invited to participate in the study. Patients were questioned with regard to their smoking habits, current contraceptive practice, age at first intercourse, and total number of sexual partners. Cytological specimens were obtained using either an Ayre's or Aylesbury spatula. Patients who had genital warts, whose partners had genital warts or whose cytology was reported as abnormal were invited to 
Table 1 Cytology results by age and sexual history

\begin{tabular}{|c|c|c|c|c|c|}
\hline & \multicolumn{3}{|c|}{ Wart or Wart Contact (117) } & \multicolumn{2}{|c|}{ Non-wart or Wart contact (55) } \\
\hline & $\begin{array}{l}\text { Normal } \\
\text { smear } \\
(56)\end{array}$ & $\begin{array}{l}\text { Current smear normal. } \\
\text { Previous abnormal smear } \\
\text { (9) }\end{array}$ & $\begin{array}{l}\text { Abnormal } \\
\text { smear } \\
(52)\end{array}$ & $\begin{array}{l}\text { Normal } \\
\text { smear } \\
(48)\end{array}$ & $\begin{array}{l}\text { Abnormal } \\
\text { smear } \\
\text { (7) }\end{array}$ \\
\hline $\begin{array}{l}\text { Age (years) } \\
\text { Age at first sexual } \\
\text { intercourse (years) }\end{array}$ & $\begin{array}{l}25.3(1.06) \\
16.7(0.23)\end{array}$ & $\begin{array}{l}23.8(1.05) \\
17 \cdot 2(0.64)\end{array}$ & $\begin{array}{l}22.8(0.76) \\
16.4(0.23)\end{array}$ & $\begin{array}{l}26.8(1.53) \\
17 \cdot 1(0.38)\end{array}$ & $\begin{array}{l}26 \cdot 4(0 \cdot 23) \\
15 \cdot 7(0 \cdot 44)\end{array}$ \\
\hline Total No of sexual partners & $5 \cdot 5(0.56)$ & $7 \cdot 6(2 \cdot 8)$ & $4.5(0.32)$ & $3.9(0.40)$ & $12 \cdot 7(3 \cdot 8)$ \\
\hline
\end{tabular}

Values $=$ Means $($ SEM $)$.

undergo colposcopic evaluation of the cervix, 2-3 months later. Biopsies were taken from colposcopically abnormal sites and fixed in buffered formol saline.

For the purpose of this study smears reported as borderline or dyskaryotic were classed as Grade $2+$. Thus those with inflammatory smears were classed as "normal" for the purpose of this study.

Statistical analysis was performed using the $\mathrm{Chi}$ square test on frequency data and the Student's $t$ test on absolute values.

\section{Results}

One hundred and eighty five women participated in the study. Of these women, 97 had a history of genital warts and 20 had partners with genital warts. Eleven women gave a history of genital warts, but had undergone procedures to the cervix such as laser ablation or biopsy, and were excluded from further analysis.

Demographic data and smear groups of patients in the study are shown in table 1 .

Two patients, not included in table 1 , had no history of warts or wart contact, but had previous smears reported as abnormal; however, current cervical cytology was reported as normal. Similarly, there were nine patients with a history of warts/wart contact, who in the past had abnormal smears but whose current smears had reverted to normal without treatment to the cervix. [See table 1). For subsequent analysis these smears were regarded as normal.

The normal smear non-wart/wart contact group was significantly older than the abnormal smear wart/ wart contact group $(p<0.05)$. Also, the mean number of sexual partners in the non-wart/wart contact group with abnormal smears was significantly greater than in any other groups $(p<0.001)$. No other significant differences could be established between the groups with regard to age, number of partners, smoking habits or current contraceptive practice.

The smear results obtained in the warts/warts contact group and the non-wart/wart contact group are shown in table 2 . There is a significantly higher rate of both borderline and dyskaryotic smears in the warts group $\left(\mathrm{Chi}^{2}=8.15, \mathrm{p}<0.01 ; \mathrm{Chi}^{2}=11.2\right.$,
Table 2 Cytology results in warts/warts contact and nonwart/wart contact group

\begin{tabular}{llll}
\hline & Warts & Wart Contact & Non-wart/Wart contact \\
Normal & $\underbrace{54}_{\begin{array}{r}55(55 \cdot 5 \%) \\
9\end{array}}$ & $50(87 \cdot 7 \%)$ \\
Grade 2+ & $\begin{aligned} 52(44 \cdot 5 \%) \\
117(100 \%)\end{aligned}$ & $\begin{array}{c}7(12 \cdot 3 \%) \\
57(100 \%)\end{array}$ \\
Total & &
\end{tabular}

Table 3 Cytology compared with biopsy results in the wart' wart contact and non-wart/wart contact group

\begin{tabular}{|c|c|c|c|c|}
\hline & $\begin{array}{l}\text { No } \\
C I N\end{array}$ & $\underset{I}{C I N}$ & $I I$ & $I I I$ \\
\hline $\begin{array}{l}\text { Warts (43) } \\
\text { Borderline (18) } \\
\text { Mild dyskaryosis (21)^ } \\
\text { Moderate dyskaryosis (2) } \\
\text { Severe dyskaryosis (2) }\end{array}$ & $\begin{array}{l}15 \\
14\end{array}$ & $\begin{array}{l}1 \\
5 \\
1\end{array}$ & $\begin{array}{l}2 \\
1 \\
1 \\
1\end{array}$ & 1 \\
\hline $\begin{array}{l}\text { Wart contact (9) } \\
\text { Borderline (6) } \\
\text { Mild dyskaryosis (1) } \\
\text { Moderate dyskaryosis (1) } \\
\text { Severe dyskaryosis (1) }\end{array}$ & $\begin{array}{l}6 \\
1 \\
1\end{array}$ & & 1 & \\
\hline $\begin{array}{l}\text { Non-wart/wart contact } \\
\text { with grade } 2+\text { smears }(7) \\
\text { Borderline }(3)^{\star} \\
\text { Mild dyskaryosis }(3) \\
\text { Moderate dyskaryosis (1) }\end{array}$ & $\begin{array}{l}2 \\
1\end{array}$ & 2 & 1 & \\
\hline
\end{tabular}

*Two patients, one in the warts group and one in the non-wart/wart contact group have defaulted from follow up and colposcopy appointments.

$\mathrm{p}<0.001$ respectively) when compared with the non wart/wart contact group. In the wart contact group there is a higher rate of grade $2+$ smears $\left(\mathrm{Chi}^{2}=9.66, \mathrm{p}<0.01\right)$.

The cytological abnormalities and biopsy findings are shown in table 3. Of those patients in the warts/ warts contact group whose current smear was normal, but who previously had abnormal smears, six underwent colposcopic examinations; no cases of CIN were found.

\section{Discussion}

The current study clearly shows an increase in 
frequency of grade $2+$ smears in women who have a history of genital warts or have been sexual contacts of men with genital warts when compared with women who do not have such a history. Previous work has demonstrated that abnormal cytology is strongly associated with the presence of HPV in cervical cells. ${ }^{12}$ In this study abnormal smears were found not only in those women with a known history of warts or wart contact, but also in some women who gave no such history. However, they may well have been in contact with HPV as sub-clinical penile HPV infection has been demonstrated by a variety of techniques. Grussendorf-Conen et $a l^{13}$ identified papillomavirus DNA in $5.8 \%$ of penile scrapes from healthy men by DNA hybridisation, whereas Chow et $\mathrm{al}^{14}$ using the polymerase chain reaction found that $80 \%$ of asymptomatic males whose female partners had genital tract HPV infection or CIN had HPV DNA demonstrated in penile biopsy specimens. Given that women with abnormal smears but no history of warts or wart contact had significantly more sexual partners than those with normal smears, it is possible that these women were exposed to the virus without their knowledge.

No cases of invasive carcinomas were found in this study; however, the study period was short. Other studies have shown progression from mild dysplasia to invasion with rates between $0 \cdot 36-4 \%,,^{15-17}$ over $21-$ 125 months. It is also clear from previous studies that there is a significant rate of progression from "mild atypia" to histologically proven CIN II or III $^{815}$ Paavonen et $a l^{8}$ reported that $13.5 \%$ of subjects attending a STD clinic with "benign atypia" progressed to biopsy confirmed CIN II or III within 30 months. Since many of the smears which were classified as benign atypias would (in the UK) be classed as "borderline" it is clearly of importance to identify these in view of their potential to progress to a stage at which treatment is regarded as appropriate. It therefore follows that any group that is at greater risk of developing "borderline" or dyskaryotic smears, for example the warts/warts contact patients, warrants more intensive surveillance, not withstanding that some of the mildly dyskaryotic smears may revert to normal. ${ }^{1516}$

CIN II and III have been demonstrated in the biposies from a proportion of patients whose smears showed mild dyskaryosis. ${ }^{15} 18$ Campion et al ${ }^{15}$ reported that 39 from $147(25.2 \%)$ women with mild dyskaryosis on routine screening had colposcopically directed biopsies showing CIN II-III. This was not confirmed in this study; the incidence of biopsy proven CIN II-III in women with mildly dyskaryotic smears being $1 / 25(4 \%)$. The reasons for this may be due to a difference in patient selection. In this study patients either had warts or had recent contact with warts. The mild cytological abnormalities found in this study might relect an acute reaction of the cervix to HPV infection.
We have also shown a low incidence of biopsy proven CIN in women with borderline smears. This too might be explained by an acute phase reaction of the cervix to HPV infection. The exact reasons for this low incidence do, however, remains speculative.

Many strategies for the management of mildly abnormal smears have been proposed including repeat cervical cytology at intervals of between 3 and 6 months ${ }^{61920}$ and referral for colposcopic examination for those with persistent abnormalities, while others advocate early colposcopic examination. ${ }^{11} 15$ Repeat cytology may miss lesions; Mitchell et al ${ }^{21}$ reported that $13.2 \%$ of women with cervical carcinoma had at least one negative smear within 36 months prior to having carcinoma diagnosed. The reasons suggested for the negative smears were suboptimal sampling and reporting errors.

The workload generated by adopting the policy of early colposcopic examination could overwhelm the system; Smith et $a^{22}$ have estimated that about 100 wholetime equivalent gynaecologists would be required to perform colposcopies if the $5 \%$ detection rate of dyskaryosis among asymptomatic women reported by Giles $e t a^{23}$ was prevalent throughout the UK. Furthermore, it has been estimated that in the Avon region by 1993 approximately $25 \%$ of the laboratory capacity would be taken by follow up smears for borderline, and mild dyskaryosis, ${ }^{24}$ and this might jeopardise five yearly call and recall. However, the value of opportunistic screening and follow up of abnormal smears should not be underestimated. Walker et $a l^{25}$ found that 67 of $93(72 \%)$ women with cervical cancer had never been screened and that three (3.2\%) had cytological abnormalities which had not been acted upon.

The average age of our patients with abnormal smears was 23.2 years. The young are a mobile population ${ }^{26}$ and may be easily lost to follow-up. In view of the findings in this study and the evidence for progression of benign atypias and mild dyskaryosis, the possibility of underestimation of the severity of lesion and the ease with which young patients can be lost to follow-up, we advocate colposcopy in all our female patients with warts or who have been in contact with warts. For other women attending a genitourinary medicine clinic in whom a smear is reported as borderline we advocate that the smear should be repeated in 3 months and if this shows borderline changes or dyskaryosis, colposcopy should then be performed. Such a policy may require modification as knowledge in this area is extended, and the possibility that borderline or mildly dyskaryotic smears may occur as an acute reaction to HPV infection requires further investigation.

Address for correspondence: Dr D Rowen, Department of Genitourinary Medicine, Addenbrooke's Hospital, Hill Road, Cambrige, CB2 2QQ, UK. 
1 Crum CP, Ikenberg H, Richart RM, Gissmann L. Human papillomavirus type 16 and early cervical neoplasia. $N$ Engl $J$ Med 1984;310:2214-9.

2 Singer A, Walker P, McCance DJ. Genital wart virus infection: nuisance or potentially lethal? $B M J 1984 ; 288: 735-7$.

3 Gissmann L, Wolnik L, Ikenberg $\mathrm{H}$, et al. Human papillomavirus types 6 and 11 DNA sequences in genital and laryngeal papillomas and in some cervical cancers. Proc Natl Acad Sci USA 1983;80:560-3.

4 British Co-operative Clinical Group. Cervical cytology screening in sexually transmitted disease clinics in the United Kingdom. Genitourin Med 1987;63:40-3.

5 Evans DMD, Hudson EA, Brown CL, et al. Terminology in gynaecological cytopathology: report of the working party of the British Society for Clinical Cytology. J Clin Pathol 1986;39:933-44.

6 Evans DMD, Hudson EA, Brown CL, Boddington MM, Hughes HE, Mackenzie EFD. Management of women with abnormal cervical smears: supplement to terminology in Gynaecological Cytopathology. J Clin Pathol 1987;40:530-1.

7 Hudson E. Cervical Cytology. BMJ 1990;300:1353-4.

8 Paavonen J, Kiviat NB, Wolner-Hanssen P, et al. Significance of mild cervical cytologic atypia in a sexually transmitted disease clinic population. Acta Cytol 1990;33:831-8.

9 Griffiths M, Sanderson D, Penna LK, Tovey SJ. Incidence and natural history of cervical epithelial abnormalities in women attending a department of genito-urinary medicine. Presented at Spring Meeting of the MSSVD 1990 Isle of Wight, UK.

10 Walker EM, Rogson J, Duncan ID. Does mild atypia warrant further investigation? Lancet 1986;ii:672-3.

11 Walkinshaw EA, Dodgson J, McCance DJ, Duncan ID. Risk factors in the development of cervical intraepithelial neoplasia in women with vulval warts. Genitourin Med 1988;64:316-20

12 Schneider A, Sawada E, Gissmann L, Shah K. Human papillomaviruses in women with a history of abnormal Papanicolaou smears and in their male partners. Obstet Gynecol 1987;69:554-62.

13 Grussendorf-Conen E, de Villiers EM, Gissmann L. Human papillomavirus genomes in penile smears of healthy men. Lancet 1986;ii: 1092 .
14 Chow VIE, Tay SK, Tham KM, Lim-Tan SK, Bernard HV. Subclinical human papillomavirus infection of the male lower genital tract: colposcopy, histology and DNA analysis. Int $J$ STD and AIDS 1991;2:41-5.

15 Campion MJ, McCance DJ, Cuzick J, Singer A. Progressive potential of mild cervical atypia: Prospective cytological, colposcopic and virological study. Lancet 1986;ii:237-40.

16 Nasiell K, Roger V, Nasiell M. Behaviour of mild cervical dysplasia during long term follow up. Obstet Gynecol 1986; 67:665-9.

17 Cotton RE, Elwood JM, Jones GM. Results of delayed follow up of abnormal cervical smears. $B M J 1986 ; 292: 799-800$.

18 Slater D, Duke E. Cervical smear policy. Lancet 1985;ii:1305.

19 Melamed MR, Flehinger BJ. Non-diagnostic squamous atypia in cervico-vaginal cytology as a risk factor for early neoplasia. Acta Cytol 1976;20:108-10.

20 Fox $\mathrm{H}$. Cervical cytology: new terminology and new demands. $B M J$ 1987;294:1307-8.

21 Mitchell H, Medley G, Giles G. Cervical cancers diagnosed after negative results on cytology: perspective in the 1980s. $B M J$ 1990;300:1622-6.

22 Smith A, Elkind A, Eardley A. Making cervical screening work. $B M J 1989 ; 298: 1662-4$.

23 Giles JA, Hudson E, Crow J, Williams D, Walker P. Colposcopic assessment of the accuracy of cervical cytology screening. $B M J$ 1988;296:1099-102.

24 Raffle AE, Alden B, Mackenzie EFD. Six years' audit of laboratory workload and rates of referral for colposcopy in a cervical screening programme in three districts. BMJ 1990; 301:907-11.

25 Walker EM, Hare MJ, Cooper P. A retrospective review of cervical cytology in women developing invasive squamous cell carcinoma. Br J Obstet Gynaecol 1983;90:1087-91.

26 Grundy EMD, Fox AJ. Migration during early married life. Eur J Population. 1985;1:237-63.

Accepted for publication 12 September 1991 